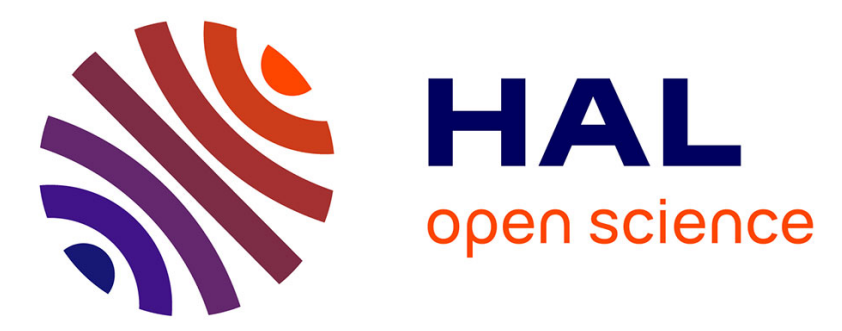

\title{
Efficient metal-free hydrosilylation of tertiary, secondary and primary amides to amines
}

Enguerrand Blondiaux, Thibault Cantat

\section{To cite this version:}

Enguerrand Blondiaux, Thibault Cantat. Efficient metal-free hydrosilylation of tertiary, secondary and primary amides to amines. Chemical Communications, 2014, 50, pp.9349-9352. 10.1039/C4CC02894E . hal-01157653

\section{HAL Id: hal-01157653 \\ https://hal.science/hal-01157653}

Submitted on 17 Nov 2015

HAL is a multi-disciplinary open access archive for the deposit and dissemination of scientific research documents, whether they are published or not. The documents may come from teaching and research institutions in France or abroad, or from public or private research centers.
L'archive ouverte pluridisciplinaire HAL, est destinée au dépôt et à la diffusion de documents scientifiques de niveau recherche, publiés ou non, émanant des établissements d'enseignement et de recherche français ou étrangers, des laboratoires publics ou privés. 


\section{ChemComm}

\section{Efficient metal-free hydrosilylation of tertiary, secondary and primary amides to amines $\dagger$}

Cite this: Chem. Commun., 2014 50, 9349

Received 18th April 2014,

Accepted 24th June 2014

DOI: $10.1039 / \mathrm{c} 4 \mathrm{cc0} 02894 \mathrm{e}$

www.rsc.org/chemcomm

Hydrosilylation of secondary and tertiary amides to amines is described using catalytic amounts of $B\left(C_{6} F_{5}\right)_{3}$. The organic catalyst enables the reduction of amides with cost-efficient, non-toxic and air stable PMHS and TMDS hydrosilanes. The methodology was successfully extended to the more challenging reduction of primary amides.

The late 1990s witnessed the birth of a novel field in homogeneous catalysis, when compelling successes were obtained in enantioselective synthesis using small organic molecules as asymmetric catalysts. ${ }^{1}$ Organocatalysis has since then witnessed a growth spurt, resulting from a better rationalization of the catalyst families and motivated by the advantages provided by metal-free catalysts. ${ }^{2}$ Indeed, organocatalysts usually combine low cost and low toxicity with an enhanced stability to moisture and air, which can circumvent classical drawbacks of many metallic catalysts. So far, organocatalysts have been applied efficiently in condensation and cycloaddition reactions, phasetransfer catalysis and oxidation chemistry, while their use in reduction chemistry has been only scarcely explored. ${ }^{3}$ In fact, the finding that molecular hydrogen could be activated using organic frustrated Lewis pairs (FLPs) enabled the metal-free catalytic hydrogenation of imines and alkenes. ${ }^{4}$ In parallel, organic Lewis acids and bases were shown to promote the hydrosilylation and hydroboration of a variety of carbonyl substrates, including $\mathrm{CO}_{2} .{ }^{5}$ These recent results are an encouragement, and future efforts in the field should focus on challenging metal catalysts for the reduction of reluctant substrates, under mild reaction conditions. In this context, the hydrosilylation of amides is an attractive alternative to classical methods utilizing reactive aluminium and boron hydrides for the synthesis of amines, as it usually proceeds with enhanced chemoselectivity. ${ }^{6}$ Nonetheless, strong resonance effects between the vacant $\pi_{\mathrm{C}=\mathrm{O}}^{*}$

E. Blondiaux, Dr. T. Cantat CEA, IRAMIS, NIMBE, CNRS UMR 3299,

91191 Gif-sur-Yvette, France.E-mail: thibault.cantat@cea.fr; Web: http://iramis. cea.fr/Pisp/thibault.cantat/index.htm; Fax: +33169086640

$\dagger$ Electronic supplementary information (ESI) available. See DOI: 10.1039/ c4cc02894e orbital and the vicinal nitrogen lone pair in amides significantly lower the electrophilicity of the $\mathrm{C}=\mathrm{O}$ group and the efficient catalytic hydrosilylation of amides remains an issue in synthetic organic chemistry. ${ }^{7}$ Tertiary and/or secondary amines can be obtained by hydrosilylation of amides and catalysts based on earth abundant metals ( $\mathrm{Fe}, \mathrm{Zn}, \mathrm{Cu}$ and $\mathrm{Co}$ ) that have been developed over the last few years for this transformation. ${ }^{8}$ Interestingly, simple bases, such as $\mathrm{Cs}_{2} \mathrm{CO}_{3}, \mathrm{KOH}, \mathrm{KO}^{t} \mathrm{Bu}$ or $\mathrm{LiHBEt}_{3}$, have emerged as hydrosilylation catalysts, lately. ${ }^{9}$ Overall, these systems offer only a partial solution to the reduction of amides as they either operate at elevated temperatures $\left(>120{ }^{\circ} \mathrm{C}\right.$ ), require the use of air sensitive hydrosilanes (such as $\left.\mathrm{PhSiH}_{3}\right)$ and/or are limited to a narrow scope of amide derivatives. These limitations have encouraged us to explore the use of metal-free catalysts in the reduction of amides to amines using hydrosilylanes. Herein, we show that the $\mathrm{B}\left(\mathrm{C}_{6} \mathrm{~F}_{5}\right)_{3}$ catalyst, combined with cost-efficient, non-toxic and air stable PMHS (polymethylhydrosiloxane) and TMDS (tetramethyldisiloxane) hydrosilanes, is a potent system for the hydrosilylation of tertiary, secondary and primary amides.

Very recently, Beller and coworkers showed that boronic acids could act as organocatalysts in the hydrosilylation of tertiary and secondary amides. ${ }^{10}$ Yet, the transformation proceeds at $110-130{ }^{\circ} \mathrm{C}$ with an excess of $\mathrm{PhSiH}_{3}$, and the turnover numbers (TONs) are very limited $(<2)$ in the reduction of primary amides. From another standpoint, Piers and coworkers demonstrated, in the late $1990 \mathrm{~s}$, the potential of $\mathrm{B}\left(\mathrm{C}_{6} \mathrm{~F}_{5}\right)_{3}$ as a catalyst in the hydrosilylation of aromatic aldehydes, ketones, and esters. ${ }^{11}$ This seminal contribution has since then been successfully applied in the hydrosilylation of alcohols, ethers, carboxylic acids, imines and olefins and reduction of $\mathrm{N}$-phenylacetamide with $\mathrm{Ph}_{2} \mathrm{SiH}_{2}$ suggests that $\mathrm{B}\left(\mathrm{C}_{6} \mathrm{~F}_{5}\right)_{3}$ could be an efficient catalyst for the hydrosilylation of amides. ${ }^{12}$

The ability of $\mathrm{B}\left(\mathrm{C}_{6} \mathrm{~F}_{5}\right)_{3}$ to catalyze the hydrosilylation of amides was first tested in the reduction of $N$-benzylbenzamide (1a). In the presence of a large catalyst loading of $20 \mathrm{~mol} \%$ $\mathrm{B}\left(\mathrm{C}_{6} \mathrm{~F}_{5}\right)_{3}$ and 1.3 equiv. of $\mathrm{PhSiH}_{3}$, dibenzylamine $2 \mathrm{a}$ is formed in a low $16 \%$ yield after $18 \mathrm{~h}$ at room temperature in toluene 
Table 1 Reduction of $\mathrm{N}$-benzylbenzamide with $\mathrm{B}\left(\mathrm{C}_{6} \mathrm{~F}_{5}\right)_{3}$

\begin{tabular}{|c|c|c|c|c|}
\hline Entry & $\mathrm{X}_{3} \mathrm{SiH}(n)$ & $\begin{array}{l}\text { Cat. loading } \\
\text { [mol\%] }\end{array}$ & $\begin{array}{l}\text { Temp. } \\
{\left[{ }^{\circ} \mathrm{C}\right]}\end{array}$ & $\begin{array}{l}\text { Yield }^{a} \\
{[\%]}\end{array}$ \\
\hline 1 & $\mathrm{PhSiH}_{3}(1.3)$ & - & 100 & 0 \\
\hline 2 & $\mathrm{PhSiH}_{3}(1.3)$ & 20 & 20 & 16 \\
\hline 3 & $\mathrm{PhSiH}_{3}(1.3)$ & 20 & 100 & 99 \\
\hline 4 & $\mathrm{PhSiH}_{3}(1.3)$ & 5 & 100 & 92 \\
\hline 5 & $\mathrm{PhSiH}_{3}(1.3)$ & 2 & 100 & 87 \\
\hline 6 & $\mathrm{PhSiH}_{3}(1.3)$ & 1 & 100 & 53 \\
\hline 7 & $\mathrm{PhSiH}_{3}(1.3)$ & 5 & 100 & $62^{b}$ \\
\hline 8 & $\mathrm{PhSiH}_{3}(1.3)$ & 5 & 80 & 14 \\
\hline 9 & PMHS (4) & 5 & 100 & 76 \\
\hline 10 & TMDS (2) & 5 & 100 & 91 \\
\hline
\end{tabular}

Reaction conditions: $N$-benzylbenzamide $1 \mathrm{a}(0.10 \mathrm{mmol})$, hydrosilane ( $n$ equiv.), $18 \mathrm{~h}$ under an inert atmosphere. ${ }^{a}$ GC/MS yield using mesitylene as an internal standard. ${ }^{b} 5 \mathrm{~h}$ reaction.

(Table 1, entry 2). Nonetheless, increasing the temperature to $100{ }^{\circ} \mathrm{C}$ leads to a quantitative conversion of $\mathbf{1 a}$ to $\mathbf{2 a}$ (Table 1 , entry 3 ) and, at $100{ }^{\circ} \mathrm{C}, 2 \mathrm{~mol} \% \mathrm{~B}\left(\mathrm{C}_{6} \mathrm{~F}_{5}\right)_{3}$ is sufficient to afford $2 \mathrm{a}$ in $87 \%$ yield (Table 1 , entry 5 ). The reaction temperature plays a significant role in the catalytic activity and, at $80{ }^{\circ} \mathrm{C}$, the conversion yield to 2 a drops to $14 \%$ (Table 1, entry 8 ). This effect likely results from the formation of an adduct between the coordinating amide substrate and the catalyst $\mathrm{B}\left(\mathrm{C}_{6} \mathrm{~F}_{5}\right)_{3}$, that must be thermally cleaved to release the active Lewis acid. To our delight, PMHS and TMDS are active reductants in the hydrosilylation of 1a, despite their lower reactivity. Using $5 \mathrm{~mol} \% \mathrm{~B}\left(\mathrm{C}_{6} \mathrm{~F}_{5}\right)_{3}, 2 \mathrm{a}$ is obtained in 76 and $91 \%$ yields in the presence of 4 equiv. of PMHS and 2 equiv. of TMDS, respectively (Table 1, entries 9 and 10). In comparison, Beller et al. have shown that benzothiophenederived boronic acids were active catalysts in the hydrosilylation of amides. ${ }^{10}$ However, boronic acids display a low activity in the reduction of secondary (and primary) amides and 1a was reduced to 2a in $67 \%$ yield, in the presence of $20 \mathrm{~mol} \%$ boronic acid catalyst and 2.4 equiv. of $\mathrm{PhSiH}_{3}$, after $24 \mathrm{~h}$ at $130{ }^{\circ} \mathrm{C}$.

The $\mathrm{B}\left(\mathrm{C}_{6} \mathrm{~F}_{5}\right)_{3}$ (cat.)-TMDS system therefore appears to be a convenient reducing medium, which combines the advantages of an organocatalyst with low cost $\left(<4 € \mathrm{~kg}^{-1}\right)$, low toxicity and the stability of the TMDS hydrosilane. The scope of reactive secondary amides was thus explored using this system (Table 2). Reduction of $N$-phenylbenzamide (1b) was quantitative, after $18 \mathrm{~h}$ at $100{ }^{\circ} \mathrm{C}$, and amine $2 \mathbf{b}$ was obtained in $94 \%$ isolated yield after hydrolysis of the reaction mixture (see the ESI $\dagger$ and entry 2 in Table 2). Replacing the phenyl ring on the carbonyl group with a methyl group did not impact the reactivity of the amide and $2 \mathrm{c}$ was isolated in $92 \%$ yield, under the same conditions (Table 2, entry 3). Yet, introduction of an aliphatic group on the nitrogen atom significantly hampers the conversion yields and 1d, $\mathbf{1 e}$ and $\mathbf{1 f}$ are converted to their corresponding amines in lower yields $(<40 \%)$ (Table 2, entries $4-6)$. The allyl derivative $1 \mathbf{k}$ is reduced to $2 \mathbf{k}$ in $41 \%$ yield, without reduction of the $\mathrm{C}=\mathrm{C}$ bond. The presence of electron withdrawing groups on the benzamide ring of $\mathbf{1 a}$ favours the reaction and the $p$-Cl- and $p$-Br-substituted $N$-benzylbenzamides are converted to $2 \mathrm{~g}$ and $\mathbf{2 h}$ in quantitative yields (Table 2, entries 7 and 8). Similarly,
Table 2 Reduction of secondary amides using $\mathrm{B}\left(\mathrm{C}_{6} \mathrm{~F}_{5}\right)_{3}$ and TMDS

Entry

Reaction conditions: amide $(0.10 \mathrm{mmol})$, TMDS $(0.20 \mathrm{mmol}), \mathrm{B}\left(\mathrm{C}_{6} \mathrm{~F}_{5}\right)_{3}$ $(0.0050 \mathrm{mmol})$, toluene $(0.30 \mathrm{~mL}), 100{ }^{\circ} \mathrm{C}, 18 \mathrm{~h} .{ }^{a} \mathrm{GC} / \mathrm{MS}$ and/or ${ }^{1} \mathrm{H}$ NMR yield using mesitylene as an internal standard. ${ }^{b}$ Isolated yields.

$2 \mathbf{i}$ is obtained in $92 \%$ yield from 1 i. In contrast, the $p$-OMe substituent somewhat deactivates the reactivity of $\mathrm{N}$-benzylbenzamide and $1 \mathrm{j}$ is converted to $2 \mathrm{j}$ in $20 \%$ yield after $18 \mathrm{~h}$ at $100{ }^{\circ} \mathrm{C}$. Overall, these results are consistent with the original mechanism unveiled by Piers et al. for the $\mathrm{B}\left(\mathrm{C}_{6} \mathrm{~F}_{5}\right)_{3}$-catalyzed hydrosilylation of carbonyl groups. ${ }^{12 f}$ Its transposition to the reduction of amides likely involves the formation of an ion pair, in which the carbonyl functionality is activated by coordination to a silylium cation while the active reductant is the $\mathrm{HB}\left(\mathrm{C}_{6} \mathrm{~F}_{5}\right)_{3}{ }^{-}$anion (Scheme 1). This pathway is therefore favoured in the presence of EWGs on the amide reactant because they weaken the amide- $B\left(\mathrm{C}_{6} \mathrm{~F}_{5}\right)_{3}$ interaction and facilitate the hydride transfer from $\mathrm{HB}\left(\mathrm{C}_{6} \mathrm{~F}_{5}\right)_{3}{ }^{-}$to the carbonyl group.

The $\mathrm{B}\left(\mathrm{C}_{6} \mathrm{~F}_{5}\right)_{3}$ (cat.)-TMDS system is also competitive or superior to known metal catalysts in the hydrosilylation of secondary amides. Among the few catalysts able to promote the hydrosilylation of secondary amides with PMHS or TMDS, $\mathrm{Zn}(\mathrm{OTf})_{2}$ displays a low reactivity and it reacts at $100{ }^{\circ} \mathrm{C},{ }^{8 a}$ with high loadings (20 mol\%), while $\mathrm{Cu}(\mathrm{OTf})_{2}$ complexes are reactive at $65{ }^{\circ} \mathrm{C} .{ }^{8 f}$

Tertiary amides are classically more reactive than secondary amides in hydrosilylation reactions. Indeed, reduction of $N, N$-dimethylbenzamide (3a) to $4 \mathbf{a}$ is quantitative after $18 \mathrm{~h}$ at $100{ }^{\circ} \mathrm{C}$ with 1 mol\% $\mathrm{B}\left(\mathrm{C}_{6} \mathrm{~F}_{5}\right)_{3}$ and 1.3 equiv. of $\mathrm{PhSiH}_{3}$. Using TMDS and PMHS as reductants and catalyst loadings of $2 \mathrm{~mol} \%$ and $5 \mathrm{~mol} \%$, respectively, $4 \mathrm{a}$ is also formed in a quantitative yield. As expected, a wide range of tertiary amides was successfully 


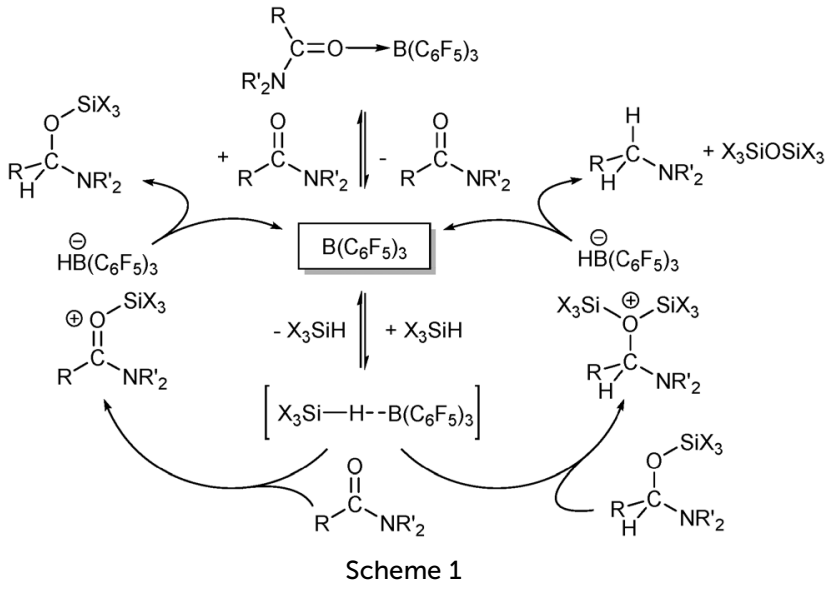

reduced using the $\mathrm{B}\left(\mathrm{C}_{6} \mathrm{~F}_{5}\right)_{3}$ (cat.)-PMHS system and both aliphatic and aromatic amides $\mathbf{3 a} \mathbf{a}-\mathbf{3} \mathbf{j}$ were converted in good to excellent yields ( $>72 \%$, Table 3 and $\left.\mathrm{ESI}^{\dagger}\right)$ ). Amide 3k exhibits a somewhat lower reactivity, presumably because of the presence of three aliphatic groups on the nitrogen and carbonyl groups and $\mathbf{4 k}$ is formed in $\mathbf{4 2} \%$ yield. Similarly, $3 \mathbf{l}$ and $\mathbf{3 m}$ afford amines $\mathbf{4 l}$ and $\mathbf{4 m}$ in 60 and $49 \%$ yields, respectively. It is noteworthy that the methodology is compatible with the presence of nitro groups and $\mathbf{4 n}$ is obtained in $82 \%$ yield when $3 \mathrm{n}$ is reduced in the presence of $\mathrm{PhSiH}_{3}$ (14\% yield when PMHS is utilized as a reductant). In contrast, the cyano group in $\mathbf{3 0}$ hampers the catalytic activity of $\mathrm{B}\left(\mathrm{C}_{6} \mathrm{~F}_{5}\right)_{3}$, presumably because of the strong coordination of the $\mathrm{CN}$ functionality to the Lewis acid catalyst. $\mathrm{B}\left(\mathrm{C}_{6} \mathrm{~F}_{5}\right)_{3}$ (cat.)/PMHS is also able to reduce enones and esters and the reduction of the amide functionality in $\mathbf{5}$ and $\mathbf{7}$ is also accompanied with the reduction of the $\mathrm{C}=\mathrm{C}$ and $-\mathrm{CO}_{2} \mathrm{Me}$ groups (eqn (4)-(6)).
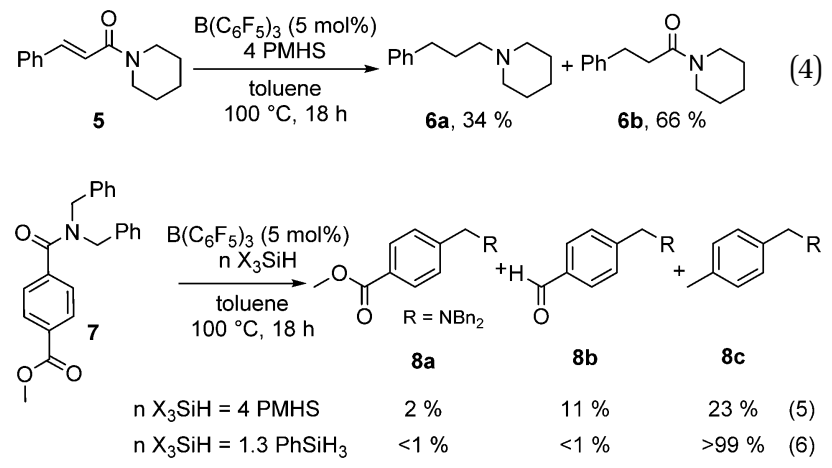

It is well recognized that primary amides are singular substrates in catalytic hydrosilylation. ${ }^{8 g, 13}$ Indeed, they display a low reactivity and can be converted to secondary amines by coupling, after subsequent hydrolysis. ${ }^{8 g, h}$ In fact, reduction of benzamide 9a with $10 \mathrm{~mol} \% \mathrm{~B}\left(\mathrm{C}_{6} \mathrm{~F}_{5}\right)_{3}$ and 2 equiv. of TMDS affords the secondary amine $2 \mathrm{a}$ in $65 \%$ yield, after $18 \mathrm{~h}$ at $100{ }^{\circ} \mathrm{C}$ (eqn (7)). As proposed by Darcel et al. and Beller et al., benzonitrile PhCN can form by slow dehydrogenative silylation of the $\mathrm{N}-\mathrm{H}$ bonds of $9 \mathbf{a}$ and subsequent elimination of a siloxane by-product. ${ }^{8 g, h}$ A plausible mechanism for the coupling reaction can thus involve the addition of nucleophilic
Table 3 Reduction of tertiary amides using $\mathrm{B}\left(\mathrm{C}_{6} \mathrm{~F}_{5}\right)_{3}$ and $\mathrm{PMHS}$

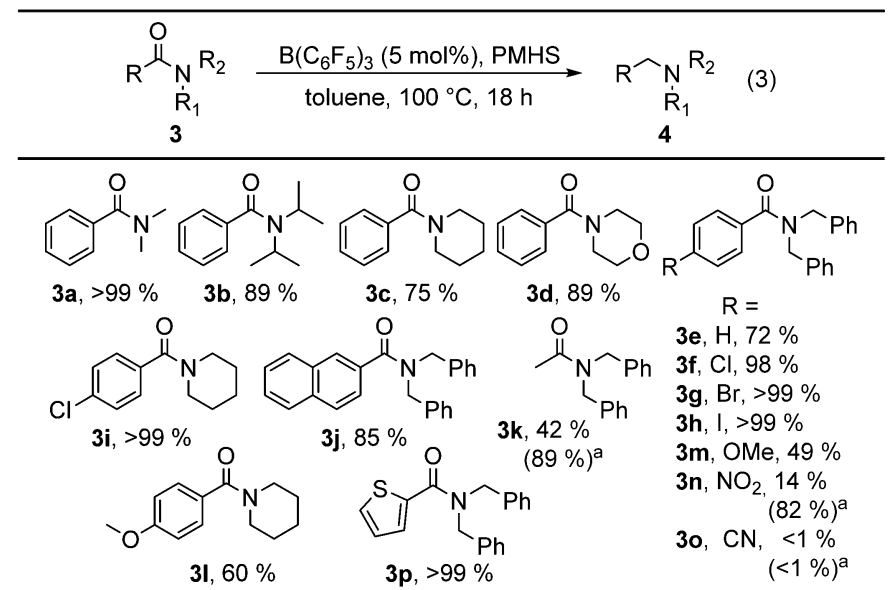

Reaction conditions: amide $(0.10 \mathrm{mmol})$, PMHS $(0.40 \mathrm{mmol}, 4$ equiv. “Si-H”), B $\left(\mathrm{C}_{6} \mathrm{~F}_{5}\right)_{3}(0.0050 \mathrm{mmol})$, toluene $(0.30 \mathrm{~mL}), 100{ }^{\circ} \mathrm{C}, 18 \mathrm{~h}$; yield determined by GC/MS using mesitylene as an internal standard. ${ }^{a}$ With $\mathrm{PhSiH}_{3}$ (0.13 mmol, 4 equiv. of "Si-H").

amide 9a to the benzonitrile intermediate. In order to prevent the coexistence of $9 a$ and benzonitrile in the reaction mixture, the rapid silylation of one $\mathrm{N}-\mathrm{H}$ bond in 9a was undertaken, using TMSCl, prior to the hydrosilylation step. Using this simple procedure, primary amines $\mathbf{1 1 a}$ and $\mathbf{1 1 b}$ were obtained in excellent 91 and $83 \%$ yields from primary amides $\mathbf{9 a}$ and $\mathbf{9 b}$, respectively (eqn (8)).

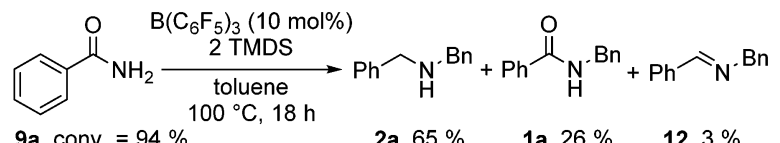

9a, conv. $=94 \% \quad$ 2a, $65 \% \quad 1 a, 26 \% \quad 12,3 \%$

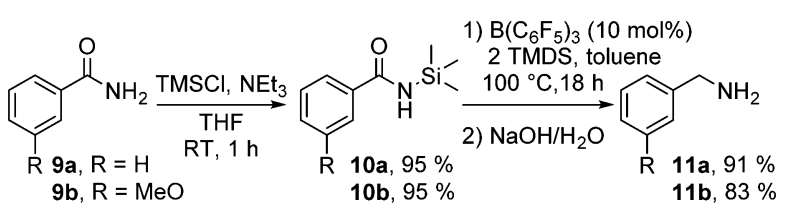

In conclusion, $\mathrm{B}\left(\mathrm{C}_{6} \mathrm{~F}_{5}\right)_{3}$ is an efficient organocatalyst for the hydrosilylation of tertiary, secondary and primary amides, with cost-efficient, non-toxic and air stable PMHS and TMDS hydrosilanes. The methodology enables the formation of tertiary, secondary and primary amines from the corresponding amides.

We acknowledge CEA, CNRS, ADEME, and the European Research Council (ERC Starting Grant Agreement no. 336467) for financial support of this work. T.C. thanks the Fondation Louis D. - Institut de France for its support.

\section{Notes and references}

1 A. Berkessel, H. Gröger and D. W. C. MacMillan, Asymmetric Organocatalysis, Wiley, 2005.

2 D. W. C. MacMillan, Nature, 2008, 455, 304.

3 (a) D. Enders, O. Niemeier and A. Henseler, Chem. Rev., 2007, 107, 5606; (b) J. Aleman and S. Cabrera, Chem. Soc. Rev., 2013, 42, 774; (c) A. Moyano and R. Rios, Chem. Rev., 2011, 111, 4703. 
4 (a) D. W. Stephan and G. Erker, Angew. Chem., Int. Ed., 2010, 49, 46; (b) G. C. Welch, R. R. S. Juan, J. D. Masuda and D. W. Stephan, Science, 2006, 314, 1124.

5 (a) M. Khandelwal and R. J. Wehmschulte, Angew. Chem., Int. Ed., 2012, 51, 7323; (b) S. N. Riduan, Y. Zhang and J. Y. Ying, Angew. Chem., Int. Ed., 2009, 48, 3322; (c) C. D. Gomes, O. Jacquet, C. Villiers, P. Thuery, M. Ephritikhine and T. Cantat, Angew. Chem., Int. Ed., 2012, 51, 187; (d) C. D. Gomes, E. Blondiaux, P. Thuery and T. Cantat, Chem. - Eur. J., 2014, 20, 7098.

$6 \mathrm{~J}$. Seyden-Penne, Reductions by the Alumino and Borohydrides in Organic Synthesis, Wiley, 1997.

7 For a recent example of an unusual hydrosilylation of amides to alcohols, see: M. Szostak, M. Spain, A. J. Eberhart and D. J. Procter, J. Am. Chem. Soc., 2014, 136, 2268.

8 (a) S. Das, D. Addis, K. Junge and M. Beller, Chemistry, 2011, 17, 12186; (b) S. Zhou, K. Junge, D. Addis, S. Das and M. Beller, Angew. Chem., Int. Ed., 2009, 48, 9507; (c) S. Das, D. Addis, S. Zhou, K. Junge and M. Beller, J. Am. Chem. Soc., 2010, 132, 1770; (d) T. Dombray, C. Helleu, C. Darcel and J.-B. Sortais, Adv. Synth. Catal., 2013, 355, 3358; (e) Y. Sunada, H. Kawakami, T. Imaoka, Y. Motoyama and H. Nagashima, Angew. Chem., Int. Ed., 2009, 48, 9511; ( $f$ ) S. Das, B. Join, K. Junge and M. Beller, Chem. Commun., 2012, 48, 2683; $(g)$ S. Das, B. Wendt, K. Moller, K. Junge and M. Beller, Angew. Chem., Int. Ed., 2012, 51, 1662; (h) B. Li, J.-B. Sortais and C. Darcel, Chem. Commun., 2013, 49, 3691.
9 (a) J. A. Fernandez-Salas, S. Manzini and S. P. Nolan, Chem. Commun., 2013, 49, 9758; (b) M. G. Manas, L. S. Sharninghausen, D. Balcells and R. H. Crabtree, New J. Chem., 2014, 38, 1694; (c) A. Volkov, F. Tinnis and H. Adolfsson, Org. Lett., 2014, 16, 680; (d) W. L. Xie, M. D. Zhao and C. M. Cui, Organometallics, 2013, 32, 7440 .

10 Y. Li, J. A. Molina de La Torre, K. Grabow, U. Bentrup, K. Junge, S. Zhou, A. Brückner and M. Beller, Angew. Chem., Int. Ed., 2013, 52, 11577.

11 D. J. Parks and W. E. Piers, J. Am. Chem. Soc., 1996, 118, 9440.

12 (a) J. M. Blackwell, E. R. Sonmor, T. Scoccitti and W. E. Piers, Org. Lett., 2000, 2, 3921; (b) M. Rubin, T. Schwier and V. Gevorgyan, J. Org. Chem., 2002, 67, 1936; (c) J. M. Blackwell, D. J. Morrison and W. E. Piers, Tetrahedron, 2002, 58, 8247; (d) M. Tan and Y. Zhang, Tetrahedron Lett., 2009, 50, 4912; (e) E. Feghali and T. Cantat, Chem. Commun., 2014, 50, 862; $(f)$ D. J. Parks, J. M. Blackwell and W. E. Piers, J. Org. Chem., 2000, 65, 3090; $(g)$ V. Gevorgyan, M. Rubin, J.-X. Liu and Y. Yamamoto, J. Org. Chem., 2001, 66, 1672; (h) D. Bézier, S. Park and M. Brookhart, Org. Lett., 2013, 15, 496.

13 For a rare example of catalytic hydrosilylation of primary amides, see: J. T. Reeves, Z. L. Tan, M. A. Marsini, Z. X. S. Han, Y. B. Xu, D. C. Reeves, H. Lee, B. Z. Lu and C. H. Senanayakea, Adv. Synth. Catal., 2013, 355, 47. 